Jurnal Jaring SainTek

Vol.1, No.1, April 2019, pp. 13-17

ISSN: 2656-9485

DOI: dx.doi.org/10.31599/jjst.v1i1.475

- 13

\title{
Pembuatan Pupuk Organik Cair dari Limbah Pasar dengan Perbandingan Hasil Menggunakan Bioaktifator Air tahu dan EM4
}

\author{
Lusi Anggraini, Vicky Anderesta Kuswoyo, Mutia Anissa Marsya* \\ Teknik Kimia, Fakultas Teknik, UBJ, Jakarta, Indonesia \\ e-mail: chy.anggraini28@gmail.com, vickyanderesta08@gmail.com, \\ mutia.annisa@dsn.ubharajaya.ac.id
}

\begin{abstract}
Abstrak
Pupuk Organik Cair (POC) mengandung banyak sisa bahan organik yang telah terurai dan siap untuk dikonsumsi oleh tanaman. Dengan memanfaatkan sisa sayuran, daun kering dan ampas tahu, diharapkan dapat meningkatkan nilai ekonomi dari sampah dan mengurangi polusi lingkungan. Pembuatan pupuk cair dengan fermentasi anaerob dilakukan dalam ember tertutup (komposter) dengan perbandingan parameter pupuk cair menggunakan bioaktivator air limbah tahu dan EM4. Karakterisasi terhadap produk pupuk cair dilakukan dengan alat Nitrogen Analyzer untuk mengetahui kadar nitrogen, kadar Posfor dengan alat spektrokopi uv-vis, serta kadar Kalium dengan dengan alat AAS. Hasil menunjukan bahwa POC dengan pembuatan menggunakan air limbah tahu, kadar $N$ total (0,38\%), Kadar Posfor (0,06\%), dan Kadar Kaliumnya (0,15\%) lebih tinggi dibandingkan dengan $P O C_{E M 4}$.
\end{abstract}

Kata kunci-Air Tahu, Bioaktifator, Komposter, Pupuk Organik Cair

\begin{abstract}
Liquid Fertilizers contain a lot of organic waste which has been decomposed and ready for consumption by plants. By utilizing the remaining vegetables, dried leaves and tofu, it is expected to increase the economic value of waste and reduce environmental pollution. Liquid fertilizer composted by anaerobic fermentation and carried out in a closed bucket (composter) with a comparison of bio-activator wastewater of tofu and EM4. The characterization of liquid fertilizer products was carried out by Nitrogen Analyzer, UV-vis spectroscopies, and AAS tools to test the levels of Nitrogen, Phosphor and Potassium respectively. The Result shown that the $N$ total levels $(0,38 \%)$, Phosphor levels $(0,06 \%)$, and potassium levels $(0,15 \%)$ of POC that made from waste water of tofu are higher than $P O C_{E M 4}$.
\end{abstract}

Keywords-Composter, Effective Microorganisms, Liquid Organic Fertilizer

\section{PENDAHULUAN}

Peningkatan mutu bahan sisa dalam kehidupan akan menghasilkan dampak positif bagi lingkungan dan juga manusia. Limbah sayur pasar yang diproduksi tiap harinya di pasar tradisional dan limbah cair tahu dari rumah industri tahu merupakan salah satu potensi sumber pencemaran air dan lingkungan karena mengandung polutan organik yang

Received 5 Des 2018; Revised 20 Jan 2019; Accepted 15 April 2019 
cukup tinggi. Kedua limbah dapat menimbulkan bau yang tidak sedap dan dapat menjadi sumber penyakit bagi lingkungan sekitar. Telah banyak penelitian untuk pemanfaatan limbah tersebut salah satunya dalam pembuatan pupuk organik cair.

Pupuk organik cair (POC) merupakan larutan hasil dari pembusukan bahan-bahan organik yang dapat berasal dari sisa tanaman, kotoran hewan, dan manusia yang kandungan unsur haranya lebih dari satu unsur, Seperti Unsur Nitrogen (N), untuk pertumbuhan tunas, batang dan daun. Unsur Fosfor (P), untuk merangsang pertumbuhan akar buah, dan biji. Unsur Kalium (K), untuk meningkatkan ketahanan tanaman terhadap serangan hama dan penyakit. Pupuk cair memiliki manfaat yang sama seperti pupuk padat yang telah dikenal selama ini. Pupuk Cair mengandung banyak sisa bahan organik yang telah terurai dan siap untuk dikonsumsi oleh tanaman, karena dalam bentuk cair, pupuk ini dapat di aplikasikan dengan cara disemprotkan ke daun dan juga ke bagian-bagian lain tanaman.

Dalam penelitian sebelumnya telah dibuktikan EM-4 merupakan bioaktivator untuk mempercepat proses pembuatan pupuk padat dan juga pupuk cair. Denta (2017) dilaporkan membuat POC dari urin kambing dengan penambahan air tahu dan EM4 mendapatkan hasil kadar nitrogen dan kalium dalam pupuk organik cair meningkat. Winda dkk, (2018) dilaporkan membuat pupuk organik cair dari air limbah tahu dengan penambahan EM4 dan menghasilkan POC yang memenuhi unsur haranya.

Pemanfaatan limbah pasar yang sudah tidak mempunyai nilai ekonomi memiliki peluang sebagai sumber pembuatan pupuk cair. Tujuan dari pada penelitian ini adalah untuk mengetahui perbedaan pengaruh penambahan air tahu sebagai bioaktifator esensial dan EM4 sebagai bioaktifator komersial dalam pembuatan POC.

\section{METODE PENELITIAN}

Pengomposan untuk mendapatkan POC dilakukan di Laboratorium Teknik Kimia Universitas Bhayangkara. Analisis kadar nitrogen, fosfor dan kalium dilakukan di Laboratorium PT Pupuk Sriwijaya Palembang. Penelitian dilakukan bulan November 2018 sampai Februari 2019.

Alat-alat yang digunakan adalah bak komposter, timbangan bahan, saringan yang digunakan untuk menyaring cairan dengan ampas hasil pengomposan. Sedangkan bahanbahan yang dipakai dalam penelitian pembuatan POC ini adalah limbah pasar (sisa sayuran), daun kering, ampas tahu, dan bioaktivator air tahu serta EM4.

\subsection{Persiapan Media}

Limbah sayur pasar yang digunakan adalah sayuran sawi, kubis dan kangkung yang sudah tidak dapat dijual. Ampas tahu dan air tahu didapat dari industri rumahan penghasil tahu dekat pasar, sedangkan daun mangga yang telah dikeringkan juga ditambahkan sebagai media. Bahan-bahan tersebut dicacah hingga hancur untuk memaksimalkan proses fermentasi.

\section{2 Pengomposan}

Bak komposer dirancang untuk proses fermentasi anaerob dilengkapi dengan kran untuk mengambil sampel POC yang telah selesai di proses. Air limbah tahu disimpan di bak komposter kemudian media yang telah hancur dimasukkan kedalam bak tersebut dan diaduk hingga merata. Berat media yang digunakan yaitu sisa sayuran $5 \mathrm{~kg}$, daun kering 2 $\mathrm{kg}$ serta ampas tahu $3 \mathrm{~kg}$. Setelah itu bak ditutup rapat dan diletakkan di tempat gelap agar proses fermentasi lebih optimal. Di bak lain sebagai pembanding, disiapkan media dengan jumlah yang sama dan di tambahkan bioaktifator EM4 500ml. Fermentasi juga 
dilakukan secara anaerob. Proses pengomposan dilakukan selama 2 minggu.

\subsection{Analisa POC}

Setelah proses fermentasi selesai, panen pupuk cair dilakukan dengan membuka keran dan ditampung pada botol plastik. POC yang dihasilkan kemudian diambil $100 \mathrm{ml}$ untuk dianalisis kandungan N, P, K dari masing-masing pupuk tersebut. Penentuan kadar Nitrogen diketahui dengan menggunkan alat Nitrogen Analyzer, penentuan kadar kalium dengan menggunakan alat $A A S$ dan penentuan kadar Posfor dengan menggunakan alat Spektrofotometri Uv-Vis. POC juga dicek tingkat keasamannya menggunakan $\mathrm{pH}$ meter.

\section{HASIL DAN PEMBAHASAN}

Penelitian ini bertujuan untuk membuat sekaligus mengetahui proses yang efektif dalam pembuatan pupuk organik cair dengan memanfaatkan sisa sayuran, daun kering dan ampas tahu dengan perbandingan penggunaan bioaktivator air limbah tahu dan EM4. Adapun untuk mengetahui efektif atau tidak proses tersebut adalah dengan melakukan analisis terhadap kandungan $\mathrm{N}, \mathrm{P}, \mathrm{K}$ dari masing-masing pupuk tersebut. Data hasil analisis di tunjukkan pada tabel 1 .

Tabel 1. Perbandingan Metode A dan Metode B

\begin{tabular}{ccccc}
\hline No. & Parameter & SNI & POC $_{\mathrm{EM} 4}$ & POC $_{\mathrm{AT}}$ \\
\hline 1. & $\mathrm{P}_{2} \mathrm{O}_{5}, \%$ & $3-6$ & 0,07 & 0,06 \\
2. & $\mathrm{K}_{2} \mathrm{O}, \%$ & $3-6$ & 0,16 & 0,15 \\
3. & Nitrogen, \% & $3-6$ & 0,31 & 0,38 \\
4. & $\mathrm{pH}$ & $4-8$ & 5.70 & 5.62 \\
\hline
\end{tabular}

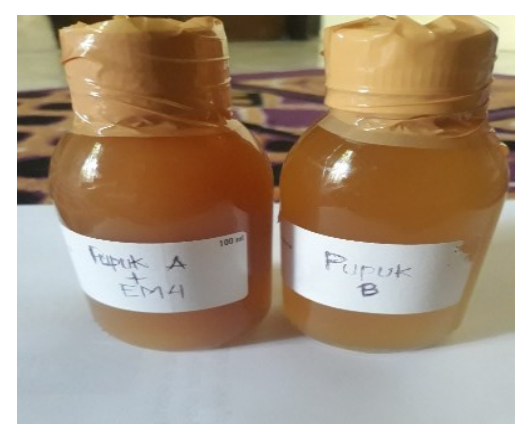

Gambar 1. Pupuk $\mathrm{A}=\mathrm{POC}_{\mathrm{EM} 4} ;$ Pupuk $\mathrm{B}=\mathrm{POC}_{\mathrm{AT}}$

Proses Fermentasi pada pembuatan pupuk cair organik di lakukan selama 14 hari yang bersifat anaerob. Dari pengujian yang telah dilakukan didapatkan kandungan Nitrogen $\mathrm{POC}_{\mathrm{EM} 4}$ lebih kecil dari pupuk $\mathrm{B}$ yaitu $0,31 \%<0,38 \%$. Kandungan utama pupuk organik adalah bahan organik, selain itu juga memiliki unsur hara $\mathrm{N}, \mathrm{P}, \mathrm{K}$, hanya saja susunan unsur hara (zat) yang dikandung oleh pupuk organik cair tidak tetap tergantung dari bahan dan cara pengomposan atau cara pembuatanya. Faktor yang diduga dapat menyebabkan perbedaan kandungan nitrogen antara $\mathrm{POC}_{\mathrm{EM} 4}$ dengan pupuk $\mathrm{POC}_{\mathrm{AT}}$ yaitu dari bioaktivator air tahu. Dilaporkan Sabilu (2015) bahwa kadar nitrogen dalam kedelai cukup tinggi dibandingkan bahan lain mencapai 5.55\%. Kedelai merupakan bahan utama pembuatan tahu sehingga $\mathrm{POC}_{\mathrm{AT}}$ memiliki kadar Nitrogen yang lebih besar yang bersumber dari sari kedelai tersebut. 
Sedangkan kandungan Posfor dan kalium dari $\mathrm{POC}_{\mathrm{AT}}$ yang didapatkan tidak jauh berbeda dengan $\mathrm{POC}_{\mathrm{EM} 4}$. Hal ini disebabkan karena komposisi sampah organik yang digunakan bervariasi serta penyusutan komposisi yang terjadi menyebabkan ketersediaan unsur hara menurun pada saat proses fermentasi.

Bila dibandingkan pada Peraturan Menteri Pertanian No 70 tahun 2011 tentang standar baku untuk pupuk organik cair, maka jenis sampel yang diperoleh pada penelitian ini belum bisa dikategorikan sebagai POC berstandar SNI karena kadar N,P,K yang didapatkan dibawah standar Baku mutu. Namun kedua POC ini masih dapat digunakan pada tanaman karena memiliki unsur hara walaupun tidak boleh diperjual belikan.

\section{KESIMPULAN}

Dari penelitian yang telah dilakukan yaitu pembuatan pupuk organik cair dari limbah pasar, daun kering, ampas tahu dan air tahu dengan perbandingan hasil dengan menggunakan bioaktivator EM4. Didapatkan hasil analisis Pupuk cair organik yaitu kadar Nitrogen $\mathrm{POC}_{\mathrm{EM} 4}(0,31 \%)$ lebih rendah dari pada kadar Nitrogen $\mathrm{POC}_{\mathrm{AT}}(0,38 \%)$. Sedangkan Kadar Posfor dan kalium dari kedua POC tersebut hampir sama. $\mathrm{POC}_{\mathrm{AT}}$ dan $\mathrm{POC}_{\mathrm{EM} 4}$ belum memenuhi standar baku mutu pupuk organic cair namun sudah dapat diaplikasikan ke tanaman karena sudah memenuhi unsur hara. Perlu adanya penelitian lebih lanjut tentang kandungan mikroorganisme dalam air limbah tahu dan juga pengembangan pembuatan $\mathrm{POC}_{\mathrm{AT}}$ dengan analisa lengkap sehingga dapat menjadikan $\mathrm{POC}_{\mathrm{AT}}$ sebagai POC berstandar nasional Indonesia (SNI).

\section{UCAPAN TERIMA KASIH}

Penelitian ini didanai oleh Lembaga Penelitian dan Pengabdian kepada Masyarakat Universitas Bhayangkara tahun 2019.

\section{DAFTAR PUSTAKA}

[1] Denta, D. (2017), Kualitas Pupuk Organik Cair Kombinasi Urin Kambing dan Limbah Cair Industri Tahu dengan Penambahan Starter EM-4. [Skripsi]. Yogyakarta: Universitas Gadjah Mada.

[2] Samsudin, W., Selomo, M., Natsir, M. F. (2018). Pengolahan Limbah Cair Industri Tahu Menjadi Pupuk Organik Cair Dengan Penambahan Effektive Mikroorganisme-4 (Em-4), Jurnal Nasional Ilmu Kesehatan. 1(2), 1-14.

[3] Foth, H. D. (1994). Dasar-Dasar Ilmu Tanah, Penerbit Erlangga, Jakarta (ID).

[4] Ulfa, S. M., Hakim, L., Sutrisno. (2018). Pembuatan Pupuk Organik Cair Berbasis Limbah Padat Biogas Pada Peternak Sapi Perah Sekar Sari "Setia Kawan" Desa Tutur Kabupaten Pasuruan, Journal of Innovation and Applied Technology. 4(1). http://dx.doi.org/10.21776/ub.jiat.004.01.14

[5] Nasution, H., Jayanti, H. D., Wahyuningsih. (2017). Optimalisasi Kadar Ph, COrganik, Rasio C/N, Dan Unsur Hara Mikro (Cu, Fe, Mn) Pupuk Organik Cair dari Limbah Tahu dan Daun Gamal (Gliricidia Sepium) Dengan Aktivator EM4, Prosiding CELSciTech.

[6] Hanafiah, Kemas Ali. (2005). Dasar Dasar Ilmu Tanah, PT. Raja Grafindo Persada, Jakarta (ID). 
[7] Jalaluddin, Nasrul, Z. A., Syafina, R. (2016). Pengolahan Sampah Organik BuahBuahan Menjadi Pupuk dengan Menggunakan efektif Mikroorganisme, Jurnal Teknologi Kimia Unimal. 5(1)

[8] Mashita, Nusa, dkk, 2008, Pengaruh Agen Dekomposer Terhadap Hasil Kualitas Hasil Pengomposan Sampah Organik Rumah Tangga. [Skripsi]. Bandung: Institut Teknologi Bandung.

[9] Peraturan Menteri Pertanian No 70 tahun 2011 tentang standar baku untuk Pupuk Organik Cair

[10] Tan, K. H. (1994). Environmental Soil Science. Manual Decker INC. New York. [USA] 